\title{
Reductive Decarboxylation of Bicyclic Prolinic Systems. A New Approach to the Enantioselective Synthesis of the Geissman-Waiss Lactone. X-ray Structure Determination of a Key Lactone Intermediate
}

\author{
João Carlos L. Ambrósio ${ }^{a}$, Regina Helena de A. Santos ${ }^{b}$ and Carlos R. D. Correia ${ }^{* a}$ \\ ${ }^{a}$ Instituto de Química, Universidade Estadual de Campinas, CP 6154, 13084-971 Campinas - SP, Brazil \\ ${ }^{b}$ Instituto de Química de São Carlos, Universidade de São Paulo, CP 780, 13560-970, São Carlos - SP, Brazil
}

\begin{abstract}
Duas sínteses do conhecido precursor de bases necínicas, $(1 R, 5 R)-N$-Cbz e $N$-Boc 2-oxa-6azabiciclo[3.3.0]octan-3-onas (lactonas de Geissman-Waiss) foram realizadas com rendimentos globais de $23 \%$ e $26 \%$, em seis e cinco etapas respectivamente, a partir de enecarbamatos endocíclicos de cinco membros enantiomericamente puros. A estratégia sintética adotada está fundamentada em uma reação de cicloadição [2+2] eficiente e altamente estereosseletiva de enecarbamatos de cinco membros com diclorocetenos, assim como em uma eficaz descarboxilação de $\alpha$-amino ácidos bicíclicos pelo método de Boger, que utiliza a redução de selenetos de acila por hidretos de estanho. Aspectos relativos a regiosseletividade da reação de oxidação de azabiciclo ciclobutanonas pelo método de Baeyer-Villiger são também descritos, com destaque para um potencial controle regioquímico advindo de aspectos estéreos em contraposição a aspectos estereoeletrônicos.
\end{abstract}

Two concise and enantioselective syntheses of the necine base precursors $(1 R, 5 R)-N-\mathrm{Cbz}$ and $N$-Boc-2-oxa-6-azabicyclo[3.3.0]octan-3-ones (Geissman-Waiss lactones) were carried out from two enantiomerically pure endocyclic five-membered enecarbamates with overall yields of $23 \%$ and $26 \%$, respectively. The synthetic strategy made use of a highly effective and stereoselective $[2+2]$ cycloaddition of enantiomerically pure endocyclic enecarbamates with dichloroketene, as well as an efficient decarboxylation step of a bicyclic $\alpha$-amino acid employing Boger's acyl selenide protocol employing tributyltin hydride. Interesting aspects concerning the regiochemical outcome of Baeyer-Villiger oxidations of bicyclic cyclobutanones are also reported, in which the usual stereoelectronic bias of Baeyer-Villiger oxidation seems to be counterbalanced by steric effects on the putative Criegee intermediate.

Keywords: Geissman-Waiss lactone, [2+2]cycloadditions, decarboxylation, pyrrolizidine alkaloids

\section{Introduction}

Pyrrolizidine alkaloids (PAs) are a large family of natural products bearing a azabicyclic[3.3.0]heptane structural core, the necine base, esterified to a diversity of mono and dicarboxylic acids (Figure 1). ${ }^{1}$ PAs possess quite interesting biological and pharmacological activities and have been the subject of much attention among chemists and biologists. ${ }^{1}$ Of the several strategies devised to prepare PAs or the necine bases, the ones relying on the key 2-oxa6-azabicyclo[3.3.0]octan-3-one (Geissman-Waiss lactone or GWL) have been extensively used since it allows easy

\footnotetext{
*e-mail: roque@iqm.unicamp.br
}

access to saturated, unsaturated and polyhydroxylated necine bases such as platynecine, retronecine and

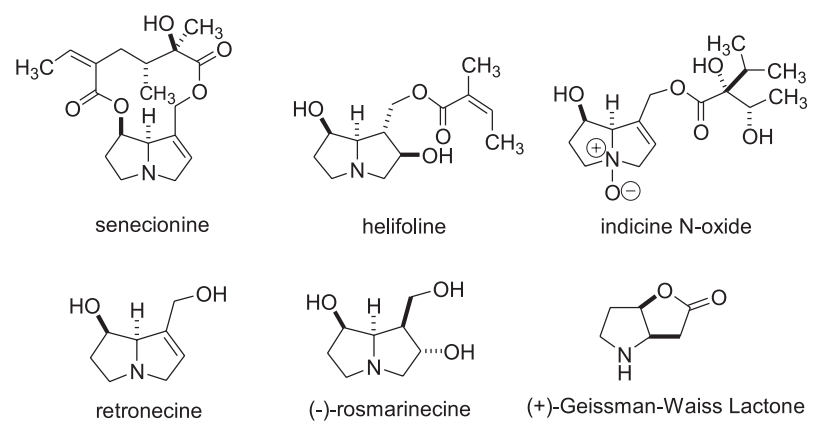

Figure 1. Examples of pyroolizidine alkaloids, necine bases and the structure of the GWL. 
croalbinecine. ${ }^{2}$ In view of the pivotal role of the GeissmanWaiss lactone in necine base synthesis, considerable efforts have been put forward to devise efficient strategies directed towards its synthesis, mainly to the stereoisomer possessing the $(1 R, 5 R)$ stereocenters, for this allows the enantioselective construction of the natural necine bases. ${ }^{3}$

In previous work we described the synthesis of the $( \pm)$ Geissman-Waiss lactone from a five-membered endocyclic enecarbamate in only four steps using a then novel approach involving the $[2+2]$ cycloaddition of enecarbamates to dichloroketenes. ${ }^{3}$ More recently, we succeeded in preparing new enantiomerically pure endocyclic enecarbamates aiming at the synthesis of several pyrrolidine containing natural products. ${ }^{4}$

In principle, to make such strategies amenable to the synthesis of enantiomerically pure $N$-heterocycles a removable stereodirecting element could be added to the endocyclic enecarbamate and removed efficiently later on. Although synthetic strategies bearing this fundamental concept are already described in the literature, ${ }^{5}$ it remained to be tested for the synthesis of enantiomerically pure $\mathrm{N}$ heterocycles from endocyclic enecarbamates. Application of such a strategy to endocyclic enecarbamates could lead to the construction of several enantiomerically pure $\mathrm{N}$ heterocycles (Figure 2). One of our first objectives envisaged testing the feasibility of this strategy for the $(1 R, 5 R)$-Geissman-Waiss lactone, in view of its pivotal role in necine base synthesis and its rather simple structure.

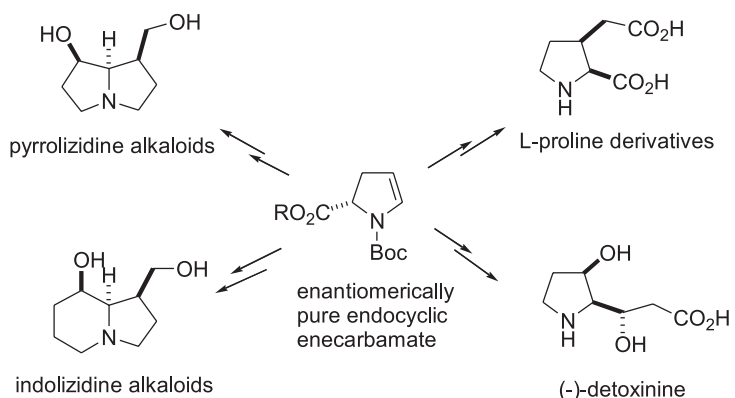

Figure 2. Natural an unnatural compouds obtained from endocyclic enecarbamates.

\section{Results and Discussion}

The enantioselective synthesis of the $(1 R, 5 R)$ Geissman-Waiss lactone started with the preparation of the enantiomerically pure enecarbamate $\mathbf{4}$ from L-proline. The synthesis proceeded in a good overall yield (41\%), as indicated in Scheme 1, employing previously developed methodology. ${ }^{4}$ A five-step synthesis was necessary to prepare the enecarbamate $\mathbf{4}$ instead of an originally planned four-step synthesis starting from L-pyroglutamic acid. This was due to the low yield obtained when preparing the tertbutylester $\mathbf{3}$ from the pyroglutamic intermediate $\mathbf{5}$ (maximum yield of $20 \%$ under the conditions shown in equation 1). Although one step longer, the route described in Scheme 1 is very efficient and permitted the synthesis of enecarbamate $\mathbf{4}$ on a multigram scale. The tert-butyl group was installed on the carboxyl group to induce the best possible stereoselectivity in the critical $[2+2]$ cycloaddition process in view of its bulk.

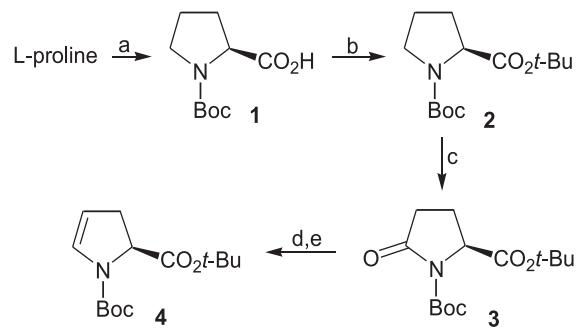

a: $(\mathrm{Boc})_{2} \mathrm{O}, 1 \mathrm{~N} \mathrm{Na}_{2} \mathrm{CO}_{3}$, dioxane, $0^{\circ} \mathrm{C}$ to rt, $30 \mathrm{~min}(98 \%)$ b:DIC DMAP $t$; Butanol $\mathrm{CH}_{2} \mathrm{Cl}_{2} \quad 0^{\circ} \mathrm{C}$ to rt $3, \mathrm{~h}(75 \%)$; c: $\mathrm{RuCl}_{3}(10 \mathrm{~mol} \%), \mathrm{NalO}_{4}, \mathrm{EtOAc}, \mathrm{rt}, 2 \mathrm{~h}(83 \%)$; d: DIBAL-H, THF, $-78^{\circ} \mathrm{C}, 1.5 \mathrm{~h}$; e: $\left(\mathrm{CF}_{3} \mathrm{CO}_{2}\right)_{2} \mathrm{O}, 2,6$-lutidine, $0^{\circ} \mathrm{C}$ to $\mathrm{rt}$, then reflux for $2.5 \mathrm{~h}$ ( $68 \%$ over two steps)

Scheme 1. Synthesis of enecarbamate 4 from L-proline.

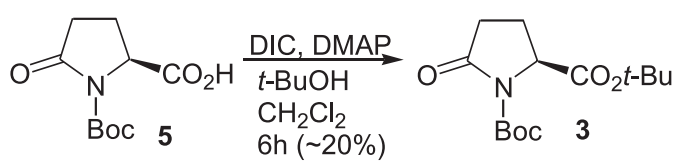

$[2+2]$ Cycloaddition of enecarbamate 4 with dichloroketene (generated in situ from dichloro acetylchloride and triethylamine) occurred smoothly to provide the desired dichlorocyclobutanone 6 in $94 \%$ isolated yield with very high diastereoselectivity. ${ }^{6}$ Cyclobutanone $\mathbf{6}$ was obtained as a single stereoisomer. Reductive dechlorination proceeded cleanly with $\mathrm{Zn} / \mathrm{Cu}$ alloy in the presence of ammonium chloride ${ }^{7}$ to provide the corresponding azabicyclic cyclobutanone 7 in $83 \%$ yield. Although not strictly necessary at this stage, the reductive dechlorination gave a more manageable intermediate (the dichlorocyclobutanone spreads on a TLC plate and is difficult to stain).

The next step in the synthesis called for a free carboxylic acid for the decarboxylation step. Attempts to selectively hydrolyze the tert-butyl ester $\mathbf{6}$ using acetic acid or formic acid failed, as well as attempts to obtain the free amino acid using trifluoroacetic acid in presence of triethylsilane (to capture the $t$-butyl cation) ${ }^{8}$ It is 


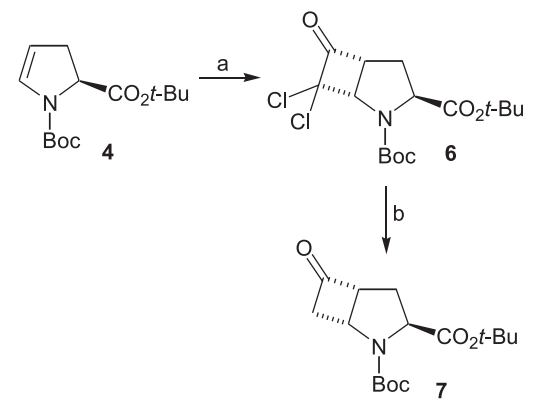

a: $\mathrm{CHCl}_{2} \mathrm{COCl}, \mathrm{Et}_{3} \mathrm{~N}, 40^{\circ} \mathrm{C}, 2 \mathrm{~h}(94 \%)$; b: $\mathrm{Zn}-\mathrm{Cu}, \mathrm{MeOH}, \mathrm{NH}_{4} \mathrm{Cl}, 1.5 \mathrm{~h}(83 \%)$

Scheme 2. Preparation of azabicyclo cyclobutanone 7.

conceivable that this failure might be related to a partial retro $[2+2]$ cycloaddition of the cyclobutanone ring of the amino acid intermediate 8 thus generating an unstable and very reactive enol-iminium intermediate that leads to several unidentified products (Scheme 3).

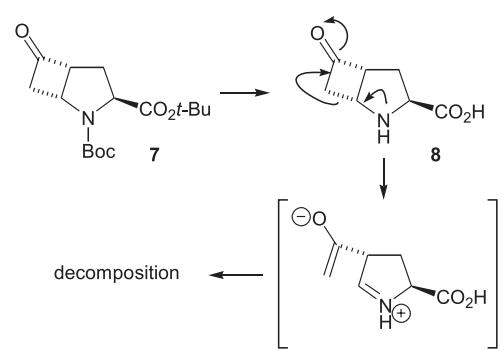

Scheme 3. Cyclobutanone opening leading to the enol-iminium.

In view of the difficulties in preparing the carboxylic acid, we proceeded to the lactone stage, hoping in this way to circumvent the unexpected cyclobutanone ring opening problem. As anticipated, Baeyer-Villiger oxidation of azabicyclic cyclobutanone 7 employing m-CPBA occurred with good yield $(80 \%)$, but with a surprising lower regioselectivity $(\mathbf{9 : 1 0}, \quad 1.6: 1$ ratio $) .{ }^{9}$ This low regioselectivity for the Baeyer-Villiger reaction was even more surprising in view of our own previous results with similar systems, ${ }^{3}$ as well as some literature precedents, since it is well-documented that oxygen insertion occurs predominantly at the more nucleophilic $\mathrm{C}-\mathrm{C}$ bond of bicyclic systems (corresponding to C5-C6 in our azabicyclic cyclobutanone 7). ${ }^{9}$ As shown later on, the presence of the ester group at $\mathrm{C} 3$ seems to strongly influence the regioselectivity of the ring expansion. We hypothesize that the stereoelectronic factors controlling the regioselectivity are somehow counterbalanced by steric factors decreasing migration of the more substituted C5 carbon. ${ }^{10}$

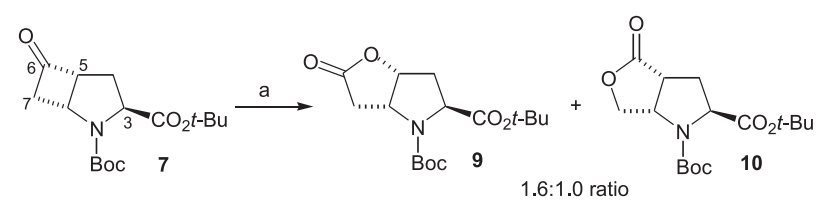

a: m-CPBA, $\mathrm{NaHCO}_{3}, \mathrm{CH}_{2} \mathrm{Cl}_{2}, \mathrm{rt}, 2 \mathrm{~h}(80 \%)$

Scheme 4. Baeyer-Villiger oxidation of cyclobutanone 7.

In spite of the low regioselectivity of the BaeyerVilliger step, the regioisomeric lactones $\mathbf{9}$ and $\mathbf{1 0}$ could be easily separated by flash chromatography (50\% isolated yield for the major lactone 9), thus providing another opportunity to test the decarboxylation reaction at the lactone stage. Full characterization of the abnormal Baeyer-Villiger product $\mathbf{1 0}$ was facilitated by the fact that the minor regioisomeric lactone formed monocrystals, which permitted its structure determination by X-ray diffraction (Figure 3).

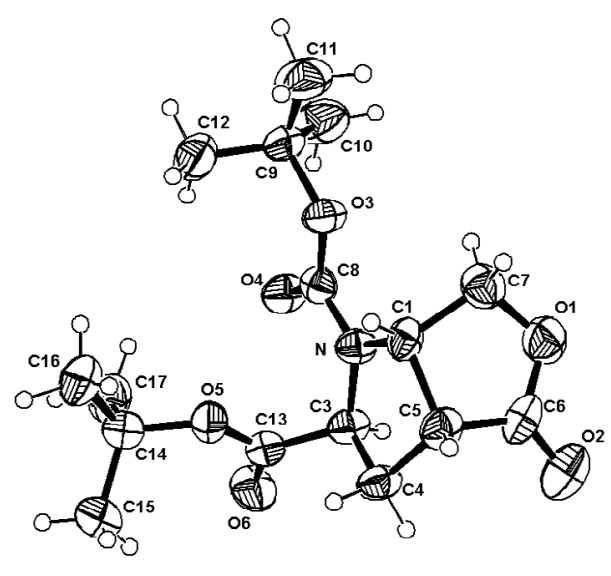

(a)

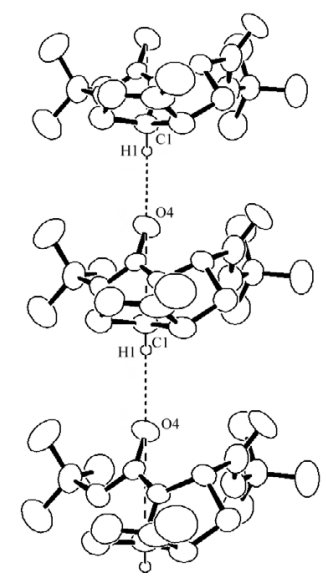

(b)

Figure 3. (a) ORTEP representation (40\% of probability) of the compound 10. (b) Molecule pile in the crystal packing. The dashed line indicates the non conventional hydrogen bond. 
The protecting groups on the major bicyclic lactone 9 were then removed with trifluoroacetic acid/triethylsilane ${ }^{8}$ to give a trifluoroacetate salt $\mathbf{1 1}$. This compound was used without further purification in the next step where the amino group of $\mathbf{1 1}$ was protected as a carbobenzyloxy group using benzylchloroformate under the conditions described in Scheme 5, providing the interesting lactone amino acid $\mathbf{1 2}$ as a stable compound.

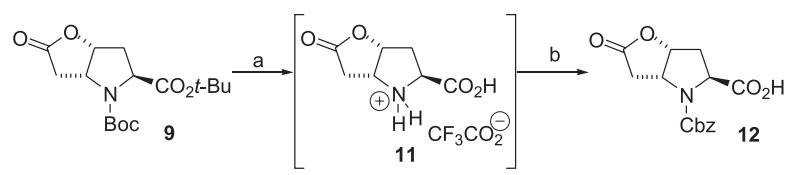

a: TFA, $\mathrm{Et}_{3} \mathrm{SiH}, \mathrm{CH}_{2} \mathrm{Cl}_{2}, 0^{\circ} \mathrm{C}$ to rt, $45 \mathrm{~min} ; \mathbf{b}: \mathrm{Cbz}-\mathrm{Cl}, \mathrm{Na}_{2} \mathrm{CO}_{3}$, rt, $1 \mathrm{~h}$

Scheme 5. Removal of the protecting group on lactone $\mathbf{9}$.

Amino acid 12 was obtained as an almost pure compound. Therefore, for practical reasons it was directly used in the decarboxylation step, employing Boger's protocol. ${ }^{11}$ Following this procedure, acid $\mathbf{1 2}$ was reacted with isobutyl chloroformate to give a putative mixed anhydride, which was further reacted with sodium phenylselenide (from the reduction of $\mathrm{Ph}_{2} \mathrm{Se}_{2}$ with $\mathrm{NaBH}_{4}$ ) to give a rather stable acyl selenide $\mathbf{1 3}$. The acyl selenide was immediately reduced with $n$-tributyltin hydride/AIBN in benzene at reflux to provide the desired $N-\mathrm{Cbz}$ Geissman-Waiss lactone $\mathbf{1 4}$ in an good overall yield of $60 \%$ from the protected bicyclic lactone $\mathbf{9}$, over four steps.

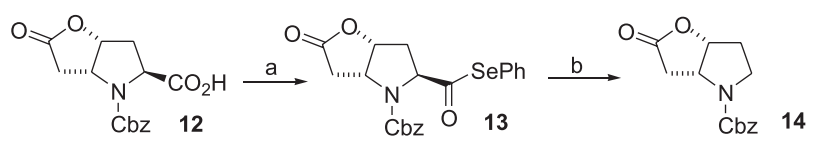

a: i) $\mathrm{ClCO}_{2} \mathrm{CH}_{2} \mathrm{CH}\left(\mathrm{CH}_{3}\right)_{2}, \mathrm{~N}$-methylmorpholine, $-10{ }^{\circ} \mathrm{C}$ to rt; ii): PhSeNa; b: $\mathrm{Bu}_{3} \mathrm{SnH}, \mathrm{AIBN}$, benzene, reflux, $3 \mathrm{~h}(60 \%$ overall yield from 9$)$

Scheme 6. Decarboxylation of carboxylic acid 12 under Boger's protocol.

Overall, the results presented above demonstrated the feasibility of the decarboxylation strategy. The (-)-(1R,5R)$N$-Cbz-Geissman-Waiss lactone $\mathbf{1 4}$ was obtained from the endocyclic enecarbamate $\mathbf{4}$ in six steps with an overall yield of $23 \%$. More importantly, these initial results also indicated that a flexible route to necine bases, the Geissman-Waiss lactone and other $N$-heterocycles could be devised in case the decarboxylation step could be performed with an intermediate cyclobutanone. A synthetic plan having the decarboxylation step prior to BaeyerVilliger ring expansion could overcome the critical low regioselectivity obtained in the transformation of cyclobutanone 7 into lactone 9.12 The hypothesis underlying this approach was the perception that the carboalkoxyl group at C3 in cyclobutanone 9 was influencing the regiochemical outcome of the BaeyerVilliger oxidation. Therefore, a second generation route to the $(1 R, 5 R)$-Geissman-Waiss lactone was devised and pursued.

In this second-generation approach to the $(1 R, 5 R)$ Geissman-Waiss lactone a new five-membered endocyclic enecarbamate was constructed. The synthesis plan called for orthogonal protection at the nitrogen and carboxylic acid functions of pyroglutamic acid. Enecarbamate 16 displays these synthetic requirements and was efficiently prepared as described in Scheme 7.

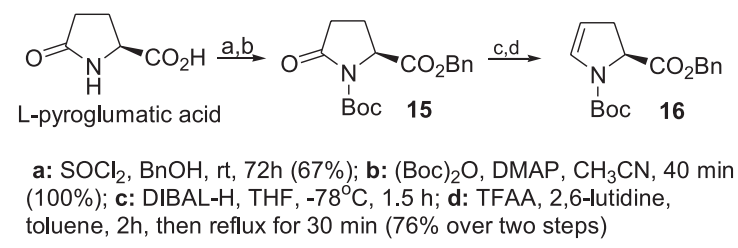

Scheme 7. Preparation of endocyclic enecarbamate $\mathbf{1 6 .}$

The first step in this new route also produced an interesting result. In carrying out the $[2+2]$ cycloaddition of enecarbamate $\mathbf{1 6}$ with dichloroketene, a significant decrease in the facial diastereoselectivity was noticed (Scheme 8). The presence of diastereomers at the cycloaddition step was not clear at first, since chromatographic separation and analyses of the dichlorocyclobutanones $\mathbf{1 7} \mathbf{a} / \mathbf{b}$ by TLC, capillary GC or HPLC was not possible. Fortunately, dechlorination of the dichlorocyclobutanones $\mathbf{1 7 a} / \mathbf{b}$ with $\mathrm{Zn}-\mathrm{Cu}$ provided a separable mixture of azabicyclic cyclobutanones $\mathbf{1 8}$ and 19 in $81 \%$ yield in a ratio of 93:07. The lower stereoselectivity for the $[2+2]$ cycloaddition was credited to the less bulky nature of the benzyl ester group at C5 of enecarbamate $\mathbf{1 6}$ when compared to the tert-butyl ester present in enecarbamate 4.

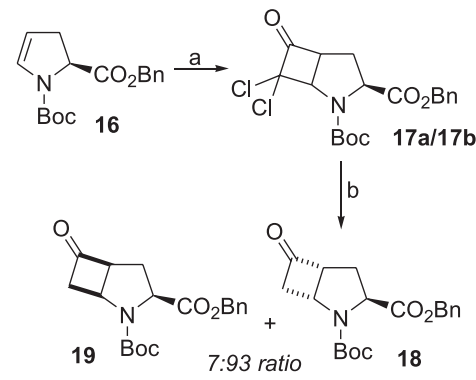

a: $\mathrm{CHCl}_{2} \mathrm{COCl}, \mathrm{Et}_{3} \mathrm{~N}, 40{ }^{\circ} \mathrm{C}, 2 \mathrm{~h}(95 \%)$; b: $\mathrm{Zn}-\mathrm{Cu}, \mathrm{MeOH}, \mathrm{NH}_{4} \mathrm{Cl}, 1.5 \mathrm{~h}(81 \%)$

Scheme 8. Synthesis of cyclobutanones 18 and 19 
The major cyclobutanone $\mathbf{1 8}$ then underwent hydrogenolysis (Scheme 9) to cleanly provide the carboxylic acid derivative 20. With this intermediate in hand we were, once again, at the position of performing the decarboxylation reaction in order to prepare the desired bicyclic cyclobutanone $\mathbf{2 2}$ in enantiomerically pure form.

The decarboxylation procedure was conducted as described in Scheme 6, without purification of the intermediates. Gratifyingly, this three-step procedure furnished the desired bicyclic cyclobutanone $\mathbf{2 2}$ in an overall yield of $49 \%$ from the benzyl ester 18. Finally, Baeyer-Villiger oxidation of the bicyclic cyclobutanone 22 provided, as anticipated, the (-)- $N$-Boc Geissman-Waiss lactone as the major regioisomer (7:1 ratio), thus confirming the greater tendency for oxygen insertion at the bridgehead C5-C6 bond in the absence of substituents at $\mathrm{C} 3$ on the 2azabicyclo[3.2.0]heptan-6-one system. The spectroscopic data of the (-)-(1R,5R)- $N$-Boc Geissman-Waiss lactone was identical in all respects to those reported in the literature. ${ }^{3}$

This second-generation synthesis of the protected Geissman-Waiss lactone was accomplished in only 5 steps with an overall yield of $26 \%$ from the endocyclic enecarbamate 16. Compared to the first-generation synthesis, this new route is shorter ( 5 steps against 6 steps), but the overall yield was only slightly better than that of the first generation synthesis ( $23 \%$ overall yield). The main reason for this difference in yields is due to the lower overall yield obtained for the decarboxylation sequence when applied to the intermediate carboxylic acid $\mathbf{2 0}$ (49\% overall yield against $60 \%$ overall yield from the carboxylic ester 9). However, it should be mentioned that the decarboxylation sequence applied to acid $\mathbf{2 0}$ leaves room for further improvements.

\section{Experimental}

Unless noted otherwise, all reactions were carried out under atmospheres of dry nitrogen or argon, in oven-dried glassware. Methylene chloride, triethylamine, 2,6-lutidine, cyclohexane, and diisopropylamine were distilled from $\mathrm{CaH}_{2}$ and, except for methylene chloride, were stored over $4 \AA$ molecular sieves. Tetrahydrofuran was distilled from sodium/benzophenone ketyl prior to use. Benzene was distilled from metallic sodium or potassium and stored over $4 \AA ̊$ molecular sieves. Trifluoroacetic anhydride was distilled from $\mathrm{P}_{2} \mathrm{O}_{5}$. Dichloroacetyl chloride and $\mathrm{N}$ methylmorpholine were previously distilled and stored under argon prior to use. Commercial BuLi hexane solution was titrated with $\mathrm{N}$-pivaloyl-o-toluidine. All other reagents were purchased from traditional commercial sources and used without further manipulations. Flash column chromatography was performed employing Merck silica gel 60 (230-400 mesh). Thin layer chromatography (TLC) was performed on Merck silica gel 60/F-254 aluminum-backed plates, and visualized by UV light and/or phosphomolybdic acid. Analytical high-performance liquid chromatography was carried out on a Varian 9010 or HP 1100 series chromatograph equipped with a refractive index detector. Chiral phase HPLC was performed employing a Chiracel OD column (250 mm x $4.6 \mathrm{~mm})$ from Diacel Chemical Industries. Capillary GLC analyses were performed on a Hewlett-Packard 6890 chromatography equipped with fused-silica capillary column ( $30 \mathrm{~m} \times 0.32 \mathrm{~mm}$ ) wall coated with HP-5. Chiral phase GLC analyses were performed employing a Chrompack WCOT Fused Silica $(25 \mathrm{~m} x$ $0.32 \mathrm{~mm}$ ) column coated with CP-Chirasil-Dex CB. Melting points were measured on a Thomas Hoover capillary melting
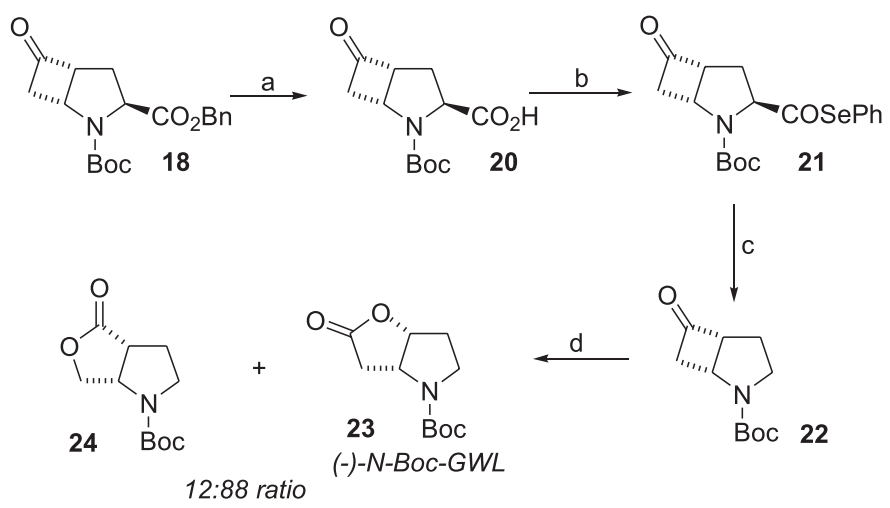

a: $\mathrm{Pd}(\mathrm{OH})_{2}, \mathrm{H}_{2}, \mathrm{MeOH}, \mathrm{rt}, 45 \mathrm{~min}$; (95\%); b: (i) isobutylchloroformate, $\mathrm{N}$-methylmorpholine, THF, $-20{ }^{\circ} \mathrm{C}(15 \mathrm{~min})$ then at it for $30 \mathrm{~min}$ and back to $-20^{\circ} \mathrm{C}$, (ii) $\mathrm{PhSeNa}$, THF/t-BuOH, $-20^{\circ} \mathrm{C}$ for 30

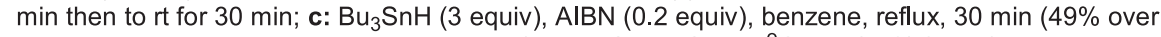
the last two steps involving three operations); $\mathbf{d}: \mathrm{H}_{2} \mathrm{O}_{2}, \mathrm{AcOH}, 4{ }^{\circ} \mathrm{C}, 3 \mathrm{~h}(80 \%$ for 23$)$ 
point apparatus and are uncorrected. Nuclear magnetic resonance spectra $\left({ }^{1} \mathrm{H}\right.$ and $\left.{ }^{13} \mathrm{C} \mathrm{NMR}\right)$ were recorded as solutions in the indicated solvents on Varian Gemini 300, Brucker AC-300P or Brucker AW-80 spectrometers. Chemical shifts are reported in parts per million ( $\delta$ units) relative to tetramethylsilane or $\mathrm{CDCl}_{3}$ (residual $\mathrm{CHCl}_{3}$ ) as internal standards ( $\left.{ }^{1} \mathrm{H} \mathrm{NMR}\right)$. When $\mathrm{CCl}_{4}$ was used as solvent a capillary containing $\mathrm{D}_{2} \mathrm{O}$ was used as internal standard. Infrared spectra were recorded on Perkin-Elmer 399B, PerkinElmer 1600 (FTIR) or Nicolet Impact 410 spectrometers. Low-resolution GC-MS was obtained on a Shimadzu QP5000, equipped with a HP-1 column (20m x 0.20mm) and high resolution mass spectra on a VG Autospec Instrument. Optical rotations were measured on a Carl Zeiss Polamat A (mercury lamp at $546 \mathrm{~nm}$ ) and corrected to the sodium D line at $589 \mathrm{~nm}$. Elemental analyses were performed on a Perkin Elmer 2400 series II CHNS/O analyzer. All measurements were carried out at the Chemistry Institute of the Universidade Estadual de Campinas.

The crystal data were collected using a turbo CAD4 diffractometer at the Instituto de Química de São Carlos, Universidade de São Paulo.

\section{Abbreviations used in this work}

AIBN = 2,2' '-azobisisobutyronitrile; Ac = acetyl; Boc = tert-butoxycarbonyl; DIC = diisopropylcarbodiimide; DMAP = 4-dimethylaminopyridine; DIBAL-H = diisobutylaluminum hydride; $t$ - $\mathrm{BuOH}=$ tert-butanol; $m$ $\mathrm{CPBA}=3$-chloroperoxybenzoic acid; $\mathrm{TFA}=$ trifluoroacetic acid; $\mathrm{Cbz}-\mathrm{Cl}=$ benzylchloroformate; $\mathrm{BnOH}=$ benzylic alcohol; $(\mathrm{Boc})_{2} \mathrm{O}=$ bis-tert-butoxycarbonyl carbonate; TFAA = trifluoroacetic acid anhydride;

Synthesis of the 2-oxo-N-(tert-butoxycarbonyl)-L-proline tert-butyl ester $(\mathbf{3})^{13}$

$1.64 \mathrm{~g}(6.1 \mathrm{mmol})$ of the L-proline tert-butyl ester 2 were dissolved in $21 \mathrm{~mL}$ of ethyl acetate. To the flask was added $61 \mathrm{~mL}$ of a $10 \% \mathrm{NaIO}_{4}$ solution $\left(6.11 \mathrm{~g}\right.$ of $\mathrm{NaIO}_{4}$ in $61 \mathrm{~mL}$ of water). The biphasic mixture was cooled with an ice/water bath and $0.21 \mathrm{~g}$ of $\mathrm{RuCl}_{3}$ was added. The bath was removed and the reaction stirred at room temperature for $3 \mathrm{~h}$. After the starting material had reacted completely (TLC analysis) the biphasic mixture was transferred to a separation funnel and the aqueous phase discarded. The organic layer was washed with a saturated solution of sodium thiosulfate and the procedure repeated until the organic layer became colorless. The organic layer was dried with $\mathrm{Na}_{2} \mathrm{SO}_{4}$ and the solvent was removed under reduced pressure. The yellowish oil was purified by flash chromatography (30\% ethyl acetate in hexane) yielding $1.44 \mathrm{~g}$ of a colorless oil ( $83 \%$ yield) corresponding to the lactam 3. Rf: 0.5 (Hex/EtOAc 30\%); IR $v_{\max } / \mathrm{cm}^{-1}: 2979$, 2933, 1795, 1739, 1716, 1369, 1313, 1155, 1022, 843, 755 (film); ${ }^{1} \mathrm{H}$ NMR (300 MHz, $\mathrm{CDCl}_{3}$ ): $\delta$ 1.47-1.49 (s, $18 \mathrm{H}), 1.92-2.08$ (1H, m), 2.15-2.65 (3H, m), 4.46 (1H, dd, ${ }^{3} J 2.6$ and $\left.7.0 \mathrm{~Hz}\right) ;{ }^{13} \mathrm{C} \mathrm{NMR}\left(75 \mathrm{MHz}, \mathrm{CDCl}_{3}\right): \delta 21.5$ $\left(\mathrm{CH}_{2}\right), 28.0\left(6 \mathrm{CH}_{3}\right), 31.0\left(\mathrm{CH}_{2}\right), 59.7(\mathrm{CH}), 82.1(\mathrm{C}), 83.2$ (C), $149.2(\mathrm{C}=\mathrm{O}), 170.4(\mathrm{C}=\mathrm{O}), 173.5(\mathrm{C}=\mathrm{O})$; EIMS $(70$ eV) $m / z:$ 57(100\%), 84, 129, 184, 214, 230, 285(M+); HRMS (EI) : Calcd for $\mathrm{C}_{14} \mathrm{H}_{23} \mathrm{NO}_{5}$ : 285.25763; Found: 285.26746 .

Synthesis of the $N$-(tert-butoxycarbonyl)-4,5-dehydro-Lproline tert-butyl ester (4)

To a solution of $300 \mathrm{mg}(1.05 \mathrm{mmol})$ of lactam 3 in $5 \mathrm{~mL}$ of dry THF at $-78^{\circ} \mathrm{C}$ were added $1.1 \mathrm{~mL}$ of a $1 \mathrm{~mol} \mathrm{~L}{ }^{-1}$ solution of DIBAL-H in toluene $(1.1 \mathrm{mmol})$. After complete consumption of the starting material (TLC analysis, after $1.5 \mathrm{~h}$ ), $5 \mathrm{~mL}$ of a saturated solution of potassium sodium tartrate tetrahydrate (Rochelle salt) were added, and the biphasic mixture was stirred for $1 \mathrm{~h}$ at room temperature. The mixture was then transferred to a separation funnel and the aqueous phase discarded. The organic layer was dried over $\mathrm{Na}_{2} \mathrm{SO}_{4}$, filtered, and the solvent was removed in vacuo. The oil obtained, corresponding to the diastereomeric mixture of hemiaminals, was characterized by IR, which indicated complete reduction of the lactam function. The product was used in the next step without further purification.

The crude diastereomeric mixture of hemiaminals was dissolved in dry toluene under nitrogen. The reaction was cooled in an ice/water bath followed by addition of 0.63 $\mathrm{mL}$ of 2,6-lutidine (5.4 mmol, 5.0 equiv) and $0.9 \mathrm{~mL}$ of a $1.2 \mathrm{~mol} \mathrm{~L}^{-1}$ solution of trifluoroacetic acid in toluene (1.1 mmol, 1.0 equiv). The ice/water bath was removed and the reaction mixture was stirred at $\mathrm{rt}$ for $3 \mathrm{~h}$. Once TLC analysis indicated complete consumption of the starting hemiaminal a reflux condenser was adapted to the round bottom flask and the reaction mixture was heated to reflux $\left(110{ }^{\circ} \mathrm{C}\right.$ ) for $30 \mathrm{~min}$. The solution was then transferred to a separation funnel and was washed twice with water and a saturated solution of $\mathrm{NaHCO}_{3}$. The organic solution was dried over anhydrous $\mathrm{Na}_{2} \mathrm{SO}_{4}$ and the solvent was removed in vacuo. The oil obtained was purified by flash chromatography ( $8 \%$ ethyl acetate in hexane) leading to $192 \mathrm{mg}$ of enecarbamate 4 as a colorless oil (68\% yield over two steps). Rf: 0.40 (Hex/EtOAc 10\%); $[\alpha]_{\mathrm{D}}{ }^{20}=-55.0$ (c 3.5, EtOAc); IR $v_{\max } / \mathrm{cm}^{-1}: 2976,2933,1749,1709,1624$, 1394, 1367. 1176, 1139, 754, 698 (film); ${ }^{1} \mathrm{H}$ NMR (300 
$\left.\mathrm{MHz}, \mathrm{CDCl}_{3}\right)$, with duplicated signals due to rotamers: $\delta$ $1.38-1.51$ (3s, 18H), 2.55 (m, 1H), 2.98 (m, 1H), 4.38 (dt, ${ }^{3} J$ 5.0 and $11.0 \mathrm{~Hz}, 1 \mathrm{H}), 4.79(\mathrm{~m}, 1 \mathrm{H}), 6.41-6.58$ (2bd, 1H); ${ }^{13} \mathrm{C} \mathrm{NMR}\left(75 \mathrm{MHz}, \mathrm{CDCl}_{3}\right.$ ), with duplicated signals due to rotamers: $\delta$ 27.9/28.2 $\left(6 \mathrm{CH}_{3}\right), 33.9 / 35.4\left(\mathrm{CH}_{2}\right), 58.1 / 58.3$ (CH), 79.4/80.0 (C), 103.1/103.6 (C), 130.3/130.8 (CH), 150.1/150.2 $(\mathrm{C}=\mathrm{O}), 169.3 / 169.6(\mathrm{C}=\mathrm{O})$; EIMS $(70 \mathrm{eV}) \mathrm{m} / \mathrm{z}$ : 57, 91(100\%), 114, 142 158, 176, 204, 220, 249, $269\left(\mathrm{M}^{+}\right)$; HRMS (EI): Calcd for $\mathrm{C}_{14} \mathrm{H}_{23} \mathrm{NO}_{4}$ : 269.16271; Found: 269.15693.

Synthesis of the N-(tert-butoxycarbonyl)-7,7-dichloro-3tert-butoxy-carbonyl-2-azabicyclo[3.2.0]heptan-6-one (6)

To a solution of enecarbamate 4 (330 $\mathrm{mg}, 1.22 \mathrm{mmol}$ ) and $\mathrm{Et}_{3} \mathrm{~N}(0.34 \mathrm{~mL}, 2.44 \mathrm{mmol})$ in $17 \mathrm{~mL}$ of cyclohexane at $40{ }^{\circ} \mathrm{C}$ was slowly added a cyclohexane solution of dichloroacetyl chloride $(0.17 \mathrm{~mL}, 1.6 \mathrm{mmol}$, dissolved in $9 \mathrm{~mL}$ of cyclohexane) using a syringe pump over a period of $2 \mathrm{~h}$. After addition of the dichloroacetyl chloride was complete the reaction mixture was stirred for an additional $20 \mathrm{~min}$. The reaction mixture was then cooled to $\mathrm{rt}$ and filtered through Celite ${ }^{\circledR}$ to remove the triethylammonium chloride salt formed in the reaction. The filtrate was rotaevaporated to give a brown-colored oil. Flash chromatography (Hex/EtOAc, 4:1) provided $436 \mathrm{mg}$ of a slightly yellow oil (96\% yield) corresponding to the dichlorocyclobutanone $\mathbf{6}$ as a homogeneous material by TLC. Rf: 0.30 (Hex/EtOAc 20\%); $[\alpha]_{\mathrm{D}}{ }^{20}=-118.7$ (c 2.5 EtOAc); IR $v_{\max } / \mathrm{cm}^{-1}: 2979,2933,1813,1739,1714,1369$, 1253, 1223, 1153, 843, 775 (film); ${ }^{1} \mathrm{H}$ NMR (300 MHz, $\left.\mathrm{CDCl}_{3}\right)$ : duplicated signals due to rotamers $\delta$ 1.47-1.52 $(2 \mathrm{~s}, 18 \mathrm{H}), 2.17-2.28(\mathrm{~m}, 1 \mathrm{H}), 2.59-2.70(\mathrm{~m}, 1 \mathrm{H}), 4.05-4.20$ $(\mathrm{m}, 1 \mathrm{H}), 4.34-4.43(\mathrm{~m}, 1 \mathrm{H}),\left[4.81\left(\mathrm{~d},{ }^{3} J 8.0 \mathrm{~Hz}\right)+4.95\left(\mathrm{~d},{ }^{3} J\right.\right.$ $8.0 \mathrm{~Hz}), 1 \mathrm{H}] ;{ }^{13} \mathrm{C} \mathrm{NMR}\left(75 \mathrm{MHz}, \mathrm{CDCl}_{3}\right)$ : duplicated signals due to rotamers $\delta 27.8 / 28.0\left(6 \mathrm{CH}_{3}\right), 30.7 / 31.6$ $\left(\mathrm{CH}_{2}\right), 57.1 / 58.5(\mathrm{CH}), 62.4 / 62.5(\mathrm{CH}), 82.0(\mathrm{C}), 82.3 / 82.5$ (C), 88.4 (C), 153.4/153.9 (C=O), 170.2/170.4(C=O), 194.9 (C=O); EIMS (70 eV) m/z: 57 (100\%), 113, 140, 178, 223, 279, 325, 379 $\left(\mathrm{M}^{+}\right)$; HRMS (EI): Calcd for $\mathrm{C}_{16} \mathrm{H}_{23} \mathrm{Cl}_{2} \mathrm{NO}_{5}$ : 379.09533; Found: 379.09833.

Synthesis of the N-(tert-butoxycarbonyl)-3-tert-butoxycarbonyl-2-azabicyclo[3.2.0] heptan-6-one (7)

A solution of dichlorocyclobutanone 6 (185 mg, 0.48 $\mathrm{mmol}$ ) in $12 \mathrm{~mL}$ of methanol (previously saturated with ammonium chloride) was bubbled with dry argon for 30 min to remove traces of oxygen. To this oxygen-free solution was then added $0.34 \mathrm{~g}$ of a previously prepared $\mathrm{Zn} / \mathrm{Cu}$ alloy. The resulting suspension was stirred for $3 \mathrm{~h}$ at rt, until TLC indicated complete consumption of the starting dichlorocyclobutanone 6. The methanol was removed in vacuo, and the residue extracted with EtOAc. The ethyl acetate suspension was filtered through Celite ${ }^{\circledR}$ and the filtrate was rotaevaporated to give a colorless oil. Flash chromatography (30\% EtOAc in hexane) provided $125 \mathrm{mg}$ (83\% yield) of a crystalline white solid corresponding to cyclobutanone 7. $\mathrm{mp} 65-68{ }^{\circ} \mathrm{C}$; Rf: 0.35 (Hex/EtOAc 30\%); $[\alpha]_{\mathrm{D}}^{20}=-170.0$ (c $2.8 \mathrm{em} \mathrm{EtOAc);} \mathrm{IR}$ $v_{\max } / \mathrm{cm}^{-1}: 2976,2933,1790,1743,1705,1385,1194$, 1136, 1028, 960, 856, 773 (film); ${ }^{1} \mathrm{H}$ NMR (300 MHz, $\mathrm{CDCl}_{3}$ ): duplicated signals due to rotamers $\delta 1.45-1.47$ (s, $18 \mathrm{H}),\left[2.01\left(\mathrm{dd},{ }^{3} \mathrm{~J} 5.0\right.\right.$ and $\left.11.0 \mathrm{~Hz}\right)+2.08\left(\mathrm{dd},{ }^{3} J 5.0\right.$ and $11.0 \mathrm{~Hz}) 1 \mathrm{H}], 2.51-2.64(\mathrm{~m}, 1 \mathrm{H}), 2.92-3.06(\mathrm{~m}, 1 \mathrm{H}), 3.26-$ $3.38(\mathrm{~m}, 1 \mathrm{H}), 3.81-3.82(\mathrm{~m}, 1 \mathrm{H}),\left[4.35\left(\mathrm{dd},{ }^{3} \mathrm{~J} 3.7\right.\right.$ and 8.8 $\mathrm{Hz})+4.43\left(\mathrm{dd},{ }^{3} \mathrm{~J} 3.7\right.$ and $\left.\left.8.8 \mathrm{~Hz}\right), 1 \mathrm{H}\right],\left[4.50\left(\mathrm{td},{ }^{3} \mathrm{~J} 2.9\right.\right.$ and $7.3 \mathrm{~Hz})$ and $4.58\left(\mathrm{td},{ }^{3} \mathrm{~J} 2.9\right.$ and $\left.\left.7.3 \mathrm{~Hz}\right), 1 \mathrm{H}\right] ;{ }^{13} \mathrm{C} \mathrm{NMR}(75$ $\left.\mathrm{MHz}, \mathrm{CDCl}_{3}\right)$ : with duplicated signals due to rotamers $\delta$ 27.9/28.3 $\left(6 \mathrm{CH}_{3}\right), 29.9\left(\mathrm{CH}_{2}\right), 49.6 / 50.2(\mathrm{CH}), 53.2 /$ 53.5 $\left(\mathrm{CH}_{2}\right), 61.2(\mathrm{CH}), 62.3 / 62.6(\mathrm{CH}), 80.5 / 80.8(\mathrm{C}), 81.6$ (C), 154.0 (C=O), 171.3/171.5 ( $\mathrm{C}=\mathrm{O}), 208.1 / 208.3(\mathrm{C}=\mathrm{O})$; EIMS (70 eV) m/z: 57 (100\%), 83, 113, 154, 211, 228, 269, $311\left(\mathrm{M}^{+}\right)$; HRMS (EI): Calcd for $\mathrm{C}_{16} \mathrm{H}_{25} \mathrm{NO}_{5}: 311.17327$; Found: 311.17271.

\section{Synthesis of the $\gamma$-lactones $\mathbf{9}$ and $\mathbf{1 0}$}

Procedure A: To a solution of cyclobutanone 7 (226 $\mathrm{mg}, 0.73 \mathrm{mmol}$ ) in $5 \mathrm{~mL}$ of dichloromethane were added $122 \mathrm{mg}$ of $\mathrm{NaHCO}_{3}(1.54 \mathrm{mmol})$ and the mixture was cooled in an ice-bath. Next, $m$-CPBA (360 mg, $1.54 \mathrm{mmol}$ ) was added, the ice-bath was removed and the reaction mixture was stirred at $\mathrm{rt}$ for $2.5 \mathrm{~h}$. After this period, the reaction mixture was transferred to a separatory funnel and washed with saturated $\mathrm{Na}_{2} \mathrm{SO}_{3}$ and saturated $\mathrm{NaHCO}_{3}$ solutions. The organic phase was separated, dried over anhydrous $\mathrm{Na}_{2} \mathrm{SO}_{4}$, filtered and the solvent was evaporated in vacuo to give a solid material. Flash chromatography (40\% EtOAc in hexane) provided $120 \mathrm{mg}$ of $\gamma$-lactone 9 and $72 \mathrm{mg}$ of $\gamma$-lactone $\mathbf{1 0}$ (combined yield of $81 \%$ ).

Procedure B: To a solution of cyclobutanone 7 (80 $\mathrm{mg}, 0.26 \mathrm{mmol}$ ) in $2 \mathrm{~mL}$ of acetic acid, at $0{ }^{\circ} \mathrm{C}$, were added $0.25 \mathrm{~mL}$ of $\mathrm{H}_{2} \mathrm{O}_{2}\left(30 \mathrm{wt} \%\right.$ in $\mathrm{H}_{2} \mathrm{O}, 75 \mathrm{mg}$ of $\left.\mathrm{H}_{2} \mathrm{O}_{2}\right)$. The icebath was then removed and the reaction mixture was stirred at $\mathrm{rt}$ for $3 \mathrm{~h}$. After this period, the reaction mixture was transferred to a separatory funnel and washed with water and saturated $\mathrm{NaHCO}_{3}$. The organic phase was separated, dried over anhydrous $\mathrm{Na}_{2} \mathrm{SO}_{4}$, filtered and the solvent was evaporated in vacuo to give a solid material. Flash chromatography (40\% EtOAc in hexane) provided $47 \mathrm{mg}$ 
of $\gamma$-lactone $\mathbf{9}$ and $28 \mathrm{mg}$ of $\gamma$-lactone $\mathbf{1 0}$ (combined yield of $90 \%$ ).

Major compound 9: $\mathrm{mp} 159-161^{\circ} \mathrm{C}$; $\mathrm{R} f: 0.40(\mathrm{Hex} /$ EtOAc $40 \%) ;[\alpha]_{\mathrm{D}}^{20}=-85.0$ (c 1.4 EtOAc); IR $v_{\text {max }} / \mathrm{cm}^{-1}$ : 2978, 2933, 1790, 1738, 1699, 1392, 1367, 1161, 1070, 847, 773 (film); ${ }^{1} \mathrm{H}$ NMR (300 $\mathrm{MHz}, \mathrm{CDCl}_{3}$ ): with duplicated signals due to rotamers $\delta 1.44-1.48(\mathrm{~s}, 18 \mathrm{H})$; $\left[2.23\left(\mathrm{t},{ }^{3} \mathrm{~J} 5.9 \mathrm{~Hz}\right)+2.28\left(\mathrm{t},{ }^{3} \mathrm{~J} 5.9 \mathrm{~Hz}\right), 1 \mathrm{H}\right], 2.55-2.64(\mathrm{~m}$, $1 \mathrm{H}), 2.80-2.88(\mathrm{~m}, 1 \mathrm{H}),\left[3.03\left(\mathrm{~d},{ }^{3} \mathrm{~J} 2.2 \mathrm{~Hz}\right)\right.$ and $3.09\left(\mathrm{~d},{ }^{3} \mathrm{~J}\right.$ $2.2 \mathrm{~Hz}), 1 \mathrm{H}], 4.30-4.37(\mathrm{~m}, 1 \mathrm{H}), 4.54-4.62(\mathrm{~m}, 1 \mathrm{H}), 4.99-$ $5.07(\mathrm{~m}, 1 \mathrm{H}) ;{ }^{13} \mathrm{C}$ NMR $\left(75 \mathrm{MHz}, \mathrm{CDCl}_{3}\right)$ : with duplicated signals due to rotamers $\delta 27.8 / 28.2\left(6 \mathrm{CH}_{3}\right), 34.7 / 35.5$ $\left(\mathrm{CH}_{2}\right), 35.7 / 36.7\left(\mathrm{CH}_{2}\right), 58.3 / 58.9(\mathrm{CH}), 59.6 / 59.8(\mathrm{CH})$, 81.1/81.3 (CH), 82.0/82.2 (C), 153.7/154.0 (C=O), 171.3/ $171.5(\mathrm{C}=\mathrm{O}), 175.2 / 175.6(\mathrm{C}=\mathrm{O})$; EIMS $(70 \mathrm{eV}) \mathrm{m} / \mathrm{z}: 57$ (100\%), 84, 131, 154, 181, 203, 245, 281, 303. Minor product 10: $\mathrm{mp} 153-155^{\circ} \mathrm{C}$; Rf: 0.35 (Hex/EtOAc $40 \%$ ); $[\alpha]_{\mathrm{D}}=-159.4$ (c 0.8 EtOAc); IR $v_{\max } / \mathrm{cm}^{-1}: 2974,2931,1751$, 1728, 1689, 1377, 1157, 102, 976, 837 (film); ${ }^{1} \mathrm{H}$ NMR (300 MHz, $\mathrm{CDCl}_{3}$ ): with duplicated signals due to rotamers $\delta 1.44-1.48(\mathrm{~s}, 18 \mathrm{H}), 2.17-2.32(\mathrm{~m}, 1 \mathrm{H}), 2.60-2.73(\mathrm{~m}, 1 \mathrm{H})$, 3.18-3.26 (m, 1H), 4.23-4.33 (m, 1H), 4.38-4.47 (m, 1H), 4.63-4.71 (m, 1H); ${ }^{13} \mathrm{C}$ NMR $\left(75 \mathrm{MHz}, \mathrm{CDCl}_{3}\right)$ : with duplicated signals due to rotamers $\delta 27.9 / 28.1\left(6 \mathrm{CH}_{3}\right)$, 35.6/35.7 $\left(\mathrm{CH}_{2}\right), 42.5 / 43.0(\mathrm{CH}), 59.6 / 59.8(\mathrm{CH}), 60.7 / 61.2$ $(\mathrm{CH}), 71.6\left(\mathrm{CH}_{2}\right), 81.1 / 81.3(\mathrm{C}), 82.0(\mathrm{C}), 153.8(\mathrm{C}=\mathrm{O})$, $171.3(\mathrm{C}=\mathrm{O}), 175.4(\mathrm{C}=\mathrm{O})$; EIMS $(70 \mathrm{eV}) \mathrm{m} / z: 57(100 \%)$, 126, 170, 226, 281.

$X$-ray structure determination of $(1 R, 3 S, 5 R)$-tert-butyl-2aza-3-[(tert-butyl)oxycarbonyl]-7-oxa-6-oxobicyclo [3.3.0]octane-2-carboxylate (lactone $\mathbf{1 0})^{14}$

The crystal data were collected using a turbo CAD4 diffractometer. A summary of the crystal data and refinement conditions is presented in Table 1. The structure was solved and refined using the WinGX system. ${ }^{15}$ The data were correct by PSISCAN ${ }^{16}\left(\mathrm{~T}_{\min }=0.9770\right.$ and $\mathrm{T}_{\max }=$ 0.9861 ). The strutucture was solved by SIR $92^{17}$ and refined by SHELX97. ${ }^{18}$ All hydrogen atoms were positioned and not refined.

The structure consists of $\mathrm{C}_{16} \mathrm{H}_{25} \mathrm{NO}_{6}$ units, with the three asymmetric carbon atoms ( $\mathrm{C} 1, \mathrm{C} 3$ and $\mathrm{C} 5)$ in the RSR configuration. The crystal packing consists of piles of molecules generated by translation in the crystallographic a axis, linked by non conventional hydrogen bond with $\mathrm{dC} 1 \ldots \mathrm{O} 4$ and angle $\mathrm{C} 1-\mathrm{H} 1 \ldots \mathrm{O} 4$ respectively equal to 3.091(9) $\AA$ and $128.9^{\circ}$. The $\mathrm{C}=\mathrm{O}$ distances in the $\mathrm{CO}_{2}-t-\mathrm{Bu}$ groups C6-O2 (1.204(9) $\AA$ ) C8-O4 (1.219(9) $\AA$ ) and C13O6 (1.234(9) $\AA$ ) are normal for this kind of compound. Crystallographic data (excluding structure factors) for the structures in this paper have been deposited with the Cambridge Crystallographic Data Centre as supplementary publication no CCDC 183539. Copies of the data can be obtained, free of charge via www.ccdc.cam.ac.uk/ conts/retrieving.html (or from the Cambridge Crystallographic Data Centre, CCDC, 12 Union Road, Cambridge CB2 1EZ, UK ; fax: +44 1223336033 ; or email: deposit@ccdc.cam.ac.uk).

Table 1. Crystal Data and Details of the Structure Determination for Compound $\mathbf{1 0}$

\begin{tabular}{|c|c|}
\hline Formula & $\mathrm{C}_{16} \mathrm{H}_{25} \mathrm{NO}_{6}$ \\
\hline Formula Weight & 327.37 \\
\hline Crystal System & Orthorhombic \\
\hline Space group & $\mathrm{P} 22_{1} 2_{1}$ \\
\hline $\mathrm{a} ; \mathrm{b} ; \mathrm{c}[\AA]$ & $\begin{array}{l}6.341(1) ; 14.618(2) ; \\
19.135(2)\end{array}$ \\
\hline $\mathrm{V}[\AA]$ & $1773.7(4)$ \\
\hline $\mathrm{Z}$ & 4 \\
\hline $\mathrm{D}($ calc $)\left[\mathrm{g} / \mathrm{cm}^{3}\right]$ & 1.226 \\
\hline$\mu(\operatorname{MoK} \alpha)\left[\mathrm{mm}^{-1}\right]$ & 0.093 \\
\hline $\mathrm{F}(000)$ & 704 \\
\hline Crystal Size [mm] & $0.15 \times 0.17 \times 0.25$ \\
\hline Temperature $(\mathrm{K})$ & 293 \\
\hline Radiation $\operatorname{MoK} \alpha[\AA]$ & 0.71073 \\
\hline$\theta \min -\max \left[^{\circ}\right]$ & $2.5,28.0$ \\
\hline Dataset & $-8: 2 ;-19: 4 ;-1: 25$ \\
\hline Tot., Uniq. Data, R(int) & $2650,2493,0.103$ \\
\hline Observed data $[\mathrm{I}>2.0 \sigma(\mathrm{I})]$ & 920 \\
\hline Nref, Npar & 2493,214 \\
\hline $\mathrm{R}, \mathrm{wR} 2, \mathrm{~S}$ & $0.0704,0.2631,0.91$ \\
\hline $\mathrm{w}=1 /\left[\sigma^{2}\left(\mathrm{Fo}^{2}\right)+(0.1386 \mathrm{P})^{2}\right]$ & where $\mathrm{P}=\left(\mathrm{Fo}^{2}+2 \mathrm{Fc}^{2}\right) / 3$ \\
\hline Min. and Max. Resd. Dens. $\left[\mathrm{e} / \AA^{3}\right]$ & $-0.30,0.30$ \\
\hline
\end{tabular}

Synthesis of the N-(carbobenzyloxy)-2-oxa-6azabicyclo[3.2.0]octan-3-one (N-Cbz-Geissman-Waiss lactone 14)

To a solution of lactone 9 ( $88 \mathrm{mg}, 0.27 \mathrm{mmol})$ in $1 \mathrm{~mL}$ of dichloromethane, at $0{ }^{\circ} \mathrm{C}$, were added triethylsilane $(0.11 \mathrm{~mL}$, $0.68 \mathrm{mmol})$ and trifluoroacetic acid $(0.27 \mathrm{~mL}, 3.53 \mathrm{mmol})$. After $45 \mathrm{~min}$, TLC indicated complete consumption of the starting lactone 9. The solvent was then removed in vacuo, the residue was dissolved in $2 \mathrm{~mL}$ of $\mathrm{H}_{2} \mathrm{O}$ followed by addition of $\mathrm{Na}_{2} \mathrm{CO}_{3}(72 \mathrm{mg})$, and $47 \mu \mathrm{L}$ of benzyl chloroformate $(0.33$ $\mathrm{mmol}$ ). The mixture was stirred for $1 \mathrm{~h}$ at rt. Next, the reaction mixture was transferred to a separatory funnel and extracted with EtOAc several times. The combined organic layers were washed with saturated $\mathrm{NH}_{4} \mathrm{Cl}$, saturated $\mathrm{NaHCO}_{3}$, saturated $\mathrm{NaCl}$ and dried over anhydrous $\mathrm{Na}_{2} \mathrm{SO}_{4}$. After filtration, the solvent was evaporated in vacuo and the crude carboxylic acid $\mathbf{1 2}$ was used in the next step without further purification. IR $v_{\text {max }} / \mathrm{cm}^{-1}: 3500-2500$ (broad); 1788, 1711, 1265, 739, 704

To a solution of the crude carboxylic acid $\mathbf{1 2}$ in $11 \mathrm{~mL}$ 
of THF at $-20^{\circ} \mathrm{C}$ were added $35 \mu \mathrm{L}$ of $N$-methylmorpholine (0.32 mmol), $42 \mu \mathrm{L}$ of isobutyl chloroformate and the reaction mixture was stirred at $-20{ }^{\circ} \mathrm{C}$ for $15 \mathrm{~min}$. The cooling bath was removed and the reaction stirred at $\mathrm{rt}$ for $30 \mathrm{~min}$. After this period the reaction was cooled again to $-20{ }^{\circ} \mathrm{C}$ followed by addition of a THF/t-BuOH solution of $\mathrm{PhSeNa}^{19}$ and stirred for $30 \mathrm{~min}$. The cooling bath was removed and the reaction stirred at $\mathrm{rt}$ for $30 \mathrm{~min}$. Removal of the solvent in vacuo provided the crude acyl selenide 13. The crude acyl selenide $\mathbf{1 3}$ was taken up in $7 \mathrm{~mL}$ of dry benzene followed by addition of $0.2 \mathrm{~mL}$ of $n$-tributyltin hydride $(0.81 \mathrm{mmol})$ and $9 \mathrm{mg}$ of $\operatorname{AIBN}(0.05 \mathrm{mmol})$. The reaction was heated to reflux for $3 \mathrm{~h}$, when TLC indicated complete consumption of the starting acyl selenide $\mathbf{1 3}$. The reaction mixture was cooled to $\mathrm{rt}$ followed by the addition $7 \mathrm{~mL}$ of a $30 \% \mathrm{KF}$ solution. The resulting biphasic system was stirred for $1 \mathrm{~h}$ and then transferred to a separatory funnel. The organic layer was dried over anhydrous $\mathrm{Na}_{2} \mathrm{CO}_{3}$, filtered and the solvent was evaporated in vacuo to furnish an oil. Flash chromatography $(40 \%$ EtOAc in hexane) provided $43 \mathrm{mg}$ of the lactone $\mathbf{1 4}$ as a crystalline solid (60\% yield over 4 steps). $[\alpha]_{\mathrm{D}}{ }^{20}=-118(c 0.6, \mathrm{MeOH})$; IR $v_{\max } / \mathrm{cm}^{-1}: 2954,2889,1782,1701,1415,1358,1223$, 1169, 1115, 1030, 984 (film); ${ }^{1} \mathrm{H} \mathrm{NMR}\left(300 \mathrm{MHz}, \mathrm{CDCl}_{3}\right.$ ): duplicated signals due to rotamers $\delta 1.95-2.14(\mathrm{~m}, 1 \mathrm{H})$, $\left[2.31\left(\mathrm{~d},{ }^{3} J 6.6 \mathrm{~Hz}\right)+2.36\left(\mathrm{~d},{ }^{3} J 5,9 \mathrm{~Hz}\right), 1 \mathrm{H}\right], 2.71-2.93(\mathrm{~m}$, 2H), 3.37-3.51 (m, 1H), 3.74-3.91 (m, 1H), 4.44-4.58 (m,1H), 5.00-5.24 (m, 3H), 7.35(s, 5H).

Synthesis of the (1S,3S,5R)-N-(tert-butoxycarbonyl)-7,7dichloro-3-benzyloxycarbonyl-2-azabicyclo [3.2.0]heptan-6-one (17a) and $(1 R, 3 S, 5 S)-N$-(tertButoxycarbonyl)-7,7-dichloro-3-benzyloxycarbonyl-2azabicyclo[3.2.0]heptan-6-one (17b)

$[2+2]$ Cycloaddition on enecarbamate $\mathbf{1 6}$ was performed as described for the cycloaddition of enecarbamate 4 with dichloroketene. Dichlorocyclobutanones $\mathbf{1 7 a} / \mathbf{1 7 b}$ were obtained as a 13:1 diastereomeric mixture after flash chromatography (EtOAc/hexane, 1:3) in 95\% yield. Data for the major cycloadduct 17a: Rf: 0.30 (Hex/EtOAc 25\%); $[\alpha]_{\mathrm{D}}{ }^{20}=-114$ (c 2.6, EtOAc); IR $v_{\max } / \mathrm{cm}^{-1}: 2978,2931$, 1813, 1747, 1712, 1454, 1369, 1184, 1153, 771, 752 (film); ${ }^{1} \mathrm{H}$ NMR (300 MHz, $\mathrm{CDCl}_{3}$ ): with duplicated signals due to rotamers $\delta 1.38-1.51(\mathrm{~s}, 9 \mathrm{H}), 2.17-2.27(\mathrm{~m}, 1 \mathrm{H}), 2.57$ $2.66(\mathrm{~m}, 1 \mathrm{H}), 4.10-4.18(\mathrm{~m}, 1 \mathrm{H}),\left[4.44\left(\mathrm{dd},{ }^{3} J 6.0 \mathrm{~Hz}\right)\right.$ and $\left.4.56\left(\mathrm{dd},{ }^{3} J 6.0 \mathrm{~Hz}\right), 1 \mathrm{H}\right],\left[4.83\left(\mathrm{~d},{ }^{3} J 8.0 \mathrm{~Hz}\right)\right.$ and $4.98\left(\mathrm{~d},{ }^{3} J\right.$ $8.0 \mathrm{~Hz}), 1 \mathrm{H}], 5.13-5.29$ (m, 2H), 7.34 (s, 5H); ${ }^{13} \mathrm{C} \mathrm{NMR}(75$ $\left.\mathrm{MHz}, \mathrm{CDCl}_{3}\right)$ : with duplicated signals due to rotamers $\delta$ 27.9/28.0 $\left(3 \mathrm{CH}_{3}\right), 30.7 / 31.6\left(\mathrm{CH}_{2}\right), 57.3 / 58.5(\mathrm{CH}), 61.5 /$ $61.6(\mathrm{CH}), 66.2 / 66.7(\mathrm{CH}), 67.3 / 67.4\left(\mathrm{CH}_{2}\right), 82.1 / 82.2(\mathrm{C})$,
88.4/88.5 (C), 128.2/128.7 (5 aromatic CH), 134.9/135.2 (aromatic C), 153.3/153.5 ( $\mathrm{C}=\mathrm{O}), 170.6 / 170.9(\mathrm{C}=\mathrm{O})$, 194.6/194.9 (C=O); EIMS (70 eV) m/z: 57 (100\%), 91, 203, 313, 413( $\left.\mathrm{M}^{+}\right), 415\left(\mathrm{M}^{+}+2\right)$.

Synthesis of the (1S,3S,5R)-N-(tert-butoxycarbonyl)-3benzyloxycarbonyl-2-azabicyclo[3.2.0]heptan-6-one (18) and (1R,3S, 5S)-N-(tert-butoxycarbonyl)-3-benzyloxycarbonyl-2-azabicyclo[3.2.0]heptan-6-one (19)

Dechlorination of dichlorocyclobutanones $\mathbf{1 7 a} / \mathbf{1 7 b}$ was carried out as performed on dichloro azabicyclic cyclobutanone 6. Flash chromatography (30\% EtOAc in hexane) provided cyclobutanones $\mathbf{1 8}$ and $\mathbf{1 9}$ in a combined yield of $81 \%$. Cyclobutanone 18: Rf: 0.30 (Hex/EtOAc $30 \%) ;[\alpha]_{\mathrm{D}}^{20}=-136$ (c 2.5, EtOAc); IR $v_{\max } / \mathrm{cm}^{-1}: 2978$, 2931, 1790, 1747, 1714, 1311, 1288, 1188, 1153, 748, 698 (film); ${ }^{1} \mathrm{H} \mathrm{NMR}\left(300 \mathrm{MHz}, \mathrm{CDCl}_{3}\right.$ ): with duplicated signals due to rotamers $\delta 1.34-1.45(\mathrm{~s}, 9 \mathrm{H}), 2.01-2.11(\mathrm{~m}$, $1 \mathrm{H}), 2.52-2.65(\mathrm{~m}, 1 \mathrm{H}), 2.91-3.05(\mathrm{~m}, 1 \mathrm{H}), 3.27-3.38(\mathrm{~m}$, $1 \mathrm{H}), 3.78-3.85(\mathrm{~m}, 1 \mathrm{H}), 4.46-4.62(\mathrm{~m}, 2 \mathrm{H}), 5.07-5.27(\mathrm{~m}$, $2 \mathrm{H}), 7.34(\mathrm{~s}, 5 \mathrm{H}) ;{ }^{13} \mathrm{C} \mathrm{NMR}\left(75 \mathrm{MHz}, \mathrm{CDCl}_{3}\right)$ : with duplicated signals due to rotamers $\delta 28.0 / 28.3\left(3 \mathrm{CH}_{3}\right)$, $29.8\left(\mathrm{CH}_{2}\right), 49.5 / 50.2(\mathrm{CH}), 53.3 / 53.5\left(\mathrm{CH}_{2}\right), 61.3(\mathrm{CH})$, $61.7(\mathrm{CH}), 62.2(\mathrm{CH}), 67.0\left(\mathrm{CH}_{2}\right), 80.8 / 81.0(\mathrm{C}), 128.1$ to 128,6 (5 aromatic $\mathrm{CH}), 135.2 / 135.4$ (aromatic $\mathrm{C}$ ); 153.7/ $154.0(\mathrm{C}=\mathrm{O}), 171.8 / 172.1(\mathrm{C}=\mathrm{O}), 207.7 / 208.0(\mathrm{C}=\mathrm{O})$; EIMS (70 eV) m/z: 57 (100\%), 91, 124, 154, 203, 245, 289, 345(M+); HRMS: Calcd: 345.15762, found: 345.15782. Compound 19: Rf: 0.25 (Hex/EtOAc 30\%); IR $v_{\max } / \mathrm{cm}^{-1}$ : 2978, 2935, 1790, 1747, 1697, 1385, 1184, 1138, 1011, 964, 748, 698 (film); ${ }^{1} \mathrm{H} \mathrm{NMR}\left(300 \mathrm{MHz}, \mathrm{CDCl}_{3}\right.$ ): with duplicated signals due to rotamers $\delta 1.23-1.34(\mathrm{~s}, 9 \mathrm{H})$, 2.04-2.11 (m, 1H), 2.31-2.40 (m, 1H), 3.22-3.48 (m, 2H), 3.80-3.84 (m, 1H), 4.51-4.70 (m, 2H); 5.02-5.29 (m, 2H), 7.35 (s, 5H); $\left.{ }^{13} \mathrm{C} \mathrm{NMR} \mathrm{(75} \mathrm{MHz}, \mathrm{CDCl}_{3}\right)$ : with duplicated signals due to rotamers $\delta 28.1 / 28.3\left(3 \mathrm{CH}_{3}\right), 29.7\left(\mathrm{CH}_{2}\right)$, 49.8/50.1 (CH), 53.3/53.4 $\left(\mathrm{CH}_{2}\right), 61.0(\mathrm{CH}), 61.3(\mathrm{CH})$, $62.4(\mathrm{CH}), 67.3\left(\mathrm{CH}_{2}\right), 80.7 / 81.1(\mathrm{C}), 128.1$ to $128.8(5$ aromatic $\mathrm{CH}$ ), $135.1 / 135.2$ (aromatic $\mathrm{C}$ ), 153.5/153.7 $(\mathrm{C}=\mathrm{O}), 172.3 / 172.6(\mathrm{C}=\mathrm{O}), 208.9 / 209.1(\mathrm{C}=\mathrm{O})$.

Synthesis of the (1S,3S,5R)-N-(tert-butoxycarbonyl)-3carboxy-2-azabicyclo[3.2.0]heptan-6-one (20)

To a solution of $186 \mathrm{mg}$ of benzyl ester $\mathbf{1 8}$ ( $0.54 \mathrm{mmol})$ in $5 \mathrm{~mL}$ of methanol were added $8 \mathrm{mg}$ of palladium hydroxide on carbon powder (Pearlman's catalyst, 20\% $\mathrm{Pd}$ ). The resulting suspension was purged with hydrogen for $30 \mathrm{~min}$ and attached to a balloon filled with hydrogen for $45 \mathrm{~min}$. Next, the suspension was filtered through 
Celite ${ }^{\circledR}$ and the solvent was removed in vacuo. The crude product was dissolved in EtOAc, transferred to a separatory funnel and extracted with saturated $\mathrm{NaHCO}_{3}$. The aqueous layer was separated, extracted with $\mathrm{CH}_{2} \mathrm{Cl}_{2}$ (twice) and acidified with $5 \% \mathrm{HCl}$ to $\mathrm{pH} 2-3$. The aqueous layer was then extracted with EtOAc and $\mathrm{CH}_{2} \mathrm{Cl}_{2}$ several times. The combined organic layers were dried over anhydrous $\mathrm{Na}_{2} \mathrm{SO}_{4}$, filtered and the solvent was evaporated in vacuo to give a viscous oil corresponding to carboxylic acid $\mathbf{2 0}$. This compound was used in the next step without further purification. Rf: $0.4\left(\mathrm{CHCl}_{3} / \mathrm{MeOH} 20 \%\right) ;[\alpha]_{\mathrm{D}}{ }^{20}=-167.9$ (c 2.3, EtOAc); IR $v_{\max } / \mathrm{cm}^{-1}: 3400-2700$ (broad); 1790, 1743, 1703, 1392, 1174, 1144; ${ }^{1} \mathrm{H}$ NMR (300 MHz, $\left.\mathrm{CDCl}_{3}\right): \delta 1.43-1.47(\mathrm{bs}, 9 \mathrm{H}), 2.10-2.29(\mathrm{~m}, 1 \mathrm{H}), 2.55-2.72$ (m, 1H), 2.92-3.16 (m, 1H), 3.27-3.43 (m, 1H), 3.82-3.96 (m, 1H), 4.43-4.66 (m, 2H), $7.62(\mathrm{sl}, 1 \mathrm{H})$; EIMS $(70 \mathrm{eV}) \mathrm{m} /$ z: 57 (100\%), 80, 113, 131, 154, 181, 199, 231, 255(M+); HRMS (EI): Calcd for $\mathrm{C}_{12} \mathrm{H}_{17} \mathrm{NO}_{5}$ : 255.11067; Found: 255.11040 .

Synthesis of the (1S,3S,5R)-N-(tert-butoxycarbonyl)-3carbophenylselenide-2-azabicyclo[3.2.0]heptan-6-one (21)

To a cooled solution of $130 \mathrm{mg}$ of the carboxylic acid $20(0.51 \mathrm{mmol})$ in $5 \mathrm{~mL}$ of dry $\mathrm{THF}$, at $-20^{\circ} \mathrm{C}$, were added $0.07 \mathrm{~mL}$ of $\mathrm{N}$-methylmorpholine $(0.61 \mathrm{mmol})$, and 0.08 $\mathrm{mL}$ of isobutylchloroformate $(0.61 \mathrm{mmol})$. The reaction mixture was stirred at $-20{ }^{\circ} \mathrm{C}$ for $15 \mathrm{~min}$, the cooling bath was removed, and the reaction mixture was stirred at $\mathrm{rt}$ for $30 \mathrm{~min}$. Next, the mixture was cooled again to $-20{ }^{\circ} \mathrm{C}$, followed by addition of a previously prepared THF/ t-BuOH solution of $\mathrm{NaSePh}$. After stirring at $-20{ }^{\circ} \mathrm{C}$ for $30 \mathrm{~min}$, the cooling bath was removed and the mixture was evaporated in vacuo. The residue was chromatographed on silica gel (15\% EtOAc in hexane) to give an oil corresponding to the acyl selenide $\mathbf{2 1}$, which was used in the decarboxylation step without further purification. IR $v_{\max } / \mathrm{cm}^{-1}: 2978,2931,1790,1709,1369$, 1173, 1138, 856, 751 (film); ${ }^{1} \mathrm{H} \mathrm{NMR}\left(300 \mathrm{MHz}, \mathrm{CDCl}_{3}\right)$ : $\delta 1.50-1.52(\mathrm{~s}, 9 \mathrm{H}), 2.17-2.30(\mathrm{~m}, 1 \mathrm{H}), 2.51-2.69(\mathrm{~m}, 1 \mathrm{H})$, $\left[3.05\left(\mathrm{t},{ }^{3} \mathrm{~J} 2.6 \mathrm{~Hz}\right)+3.10\left(\mathrm{t},{ }^{3} \mathrm{~J} 2.6 \mathrm{~Hz}\right), 1 \mathrm{H}\right], 3.31-3.49(\mathrm{~m}$, $1 \mathrm{H}), 3.86-3.97$ (m, $1 \mathrm{H}), 4.54-4.80(\mathrm{~m}, 2 \mathrm{H}), 7.35-7.42(\mathrm{~m}$, $3 \mathrm{H}), 7.44-7.52(\mathrm{~m}, 2 \mathrm{H})$.

Synthesis of the (1S,3S,5R)-N-(tert-butoxycarbonyl)-2azabicyclo[3.2.0]heptan-6-one (22)

The procedure used was identical to the one described for the conversion of the acyl selenide $\mathbf{1 3}$ to the GeissmanWaiss lactone 14. The acyl selenide 21 was used without purification and $130 \mathrm{mg}$ of the carboxylic acid 20 provided $52 \mathrm{mg}$ of the cyclobutanone $\mathbf{2 2}$ (49\% overall yield over two steps). Rf: 0.20 (Hex/EtOAc 30\%); $[\alpha]_{\mathrm{D}}{ }^{20}=-170.0$ (c 1.7, EtOAc); IR $v_{\max } / \mathrm{cm}^{-1}: 2976,2933,2889,1782,1693$, 1398, 1169, 1117, 984, 903, 773 (film); ${ }^{1} \mathrm{H}$ NMR (300 $\left.\mathrm{MHz}, \mathrm{CDCl}_{3}\right)$ : some duplicated signals due to rotamers $\delta$ 1.41 (s, 9H), 1.88-2.05 (m, 1H), 2.15-2.26 (m, 1H), [2.82 $(\mathrm{bs})+2.88(\mathrm{bs}), 1 \mathrm{H}], 3.24-3.51(\mathrm{~m}, 2 \mathrm{H}), 3.65-3.96(\mathrm{~m}, 2 \mathrm{H})$, $[4.43$ (bs) + 4.68 (bs), $\left.1 \mathrm{H}] ;{ }^{13} \mathrm{C} \mathrm{NMR} \mathrm{(75} \mathrm{MHz}, \mathrm{CDCl}_{3}\right)$ : some duplicated signals due to rotamers $\delta 28.4\left(3 \mathrm{CH}_{3}\right)$, $29.7\left(\mathrm{CH}_{2}\right), 46.2\left(\mathrm{CH}_{2}\right), 48.3(\mathrm{CH}), 53.7\left(\mathrm{CH}_{2}\right), 63.6 / 64.5$ $(\mathrm{CH}), 80.0(\mathrm{C}), 154.1(\mathrm{C}=\mathrm{O}), 210.0(\mathrm{C}=\mathrm{O})$; EIMS $(70 \mathrm{eV})$ $m / z: 57,69,113,138$ (100\%), 155, 169, 184, 196, 211( $\left.{ }^{+}\right)$; HRMS (EI): Calcd for $\mathrm{C}_{11} \mathrm{H}_{17} \mathrm{NO}_{3}$ : 211.12084; found: 211.11957.

Synthesis of the (1R,5R)-N-tert-butoxycarbonyl-2-oxa-6azabicyclo[3.3.0]octan-3-one (Geissman-Waiss lactone 23)

To a solution of $40 \mathrm{mg}$ of cyclobutanone 22 (0.19 mmol) in $1 \mathrm{~mL}$ of acetic acid, at $\sim 4{ }^{\circ} \mathrm{C}$ (ice-bath) were added $0.02 \mathrm{~mL}$ of $30 \% \mathrm{H}_{2} \mathrm{O}_{2}$. The ice-bath was removed and the mixture was stirred at $\mathrm{rt}$ for $3 \mathrm{~h}$. Next, $10 \mathrm{~mL}$ of $\mathrm{CH}_{2} \mathrm{Cl}_{2}$ were added to the reaction mixture, the solution was transferred to a separatory funnel and extracted with $\mathrm{H}_{2} \mathrm{O}$ and saturated $\mathrm{NaHCO}_{3}$. The combined organic layers were dried over anhydrous $\mathrm{MgSO}_{4}$, filtered, and evaporated in vacuo. Flash chromatography (40\% EtOAc in hexane) provided $34 \mathrm{mg}$ of the (-)-Geissman-Waiss lactone $\mathbf{2 3}$ (80\% yield). $[\alpha]_{\mathrm{D}}{ }^{20}=-122.2$ (c 1.0, EtOAc); IR $v_{\max } / \mathrm{cm}^{-1}: 2978$, 2935, 2889, 1790, 1693, 1396, 1169, 1115, 984, 903, 771; ${ }^{1} \mathrm{H}$ NMR (300 MHz, $\left.\mathrm{CDCl}_{3}\right): \delta 1.47(\mathrm{~s}, 9 \mathrm{H}), 1.94-2.11(\mathrm{~m}$, $1 \mathrm{H}),\left[2.27\left(\mathrm{~d},{ }^{3} \mathrm{~J} 6.0 \mathrm{~Hz}\right)\right.$ and $\left.2.32\left(\mathrm{~d},{ }^{3} \mathrm{~J} 6.0 \mathrm{~Hz}\right), 1 \mathrm{H}\right], 2.72$ $2.86(\mathrm{~m}, 1 \mathrm{H}), 3.28-3.42(\mathrm{~m}, 1 \mathrm{H}),\left[3.69\left(\mathrm{t},{ }^{3} J 9.9 \mathrm{~Hz}\right), 3.79(\mathrm{t}\right.$, $\left.\left.{ }^{3} J 9.9 \mathrm{~Hz}\right), 1 \mathrm{H}\right], 4.36-4.48(\mathrm{~m}, 1 \mathrm{H}), 5.06\left(\mathrm{bd},{ }^{3} \mathrm{~J} 4.0 \mathrm{~Hz}, 1 \mathrm{H}\right)$. ${ }^{13} \mathrm{C}$ NMR $\left(75 \mathrm{MHz}, \mathrm{CDCl}_{3}\right): \delta 28.4\left(3 \mathrm{CH}_{3}\right), 30.1 / 30.6$ $\left(\mathrm{CH}_{2}\right), 35.8 / 36.6\left(\mathrm{CH}_{2}\right), 43.9 / 44.4\left(\mathrm{CH}_{2}\right), 57.8(\mathrm{CH}), 80.5$ $(\mathrm{CH}), 83.1 / 84.1(\mathrm{C}), 153.2 / 153.7(\mathrm{C}=\mathrm{O}), 175.4 / 175.8$ $(\mathrm{C}=\mathrm{O})$.

\section{Conclusions}

The syntheses of the important necine base precursors, $(1 R, 5 R)-N$-carbobenzyloxy-2-ox a-6-azabicyclo [3.3.0]octan-3-one 14 and $(1 R, 5 R)-N$-tert-butoxycarbonyl2-oxa-6-azabicyclo[3.3.0] octan-3-one 23 (Geissman-Waiss lactones) were accomplished from the enantiomerically pure endocyclic enecarbamates $\mathbf{4}$ and $\mathbf{1 6}$ with overall yields of $23 \%$ and $26 \%$, respectively. The synthetic strategy relied on an efficient and stereoselective $[2+2]$ cycloaddition 
reaction of the enecarbamates with dichloroketene that established the correct configuration of the chiral centers at $\mathrm{C} 1$ and $\mathrm{C} 5$ of the target compound. The stereocontrolling carboxylic ester groups present at $\mathrm{C} 5$ in the chiral endocyclic enecarbamates were efficiently removed by applying Boger's decarboxylation protocol to the respective carboxylic acids. Interesting aspects concerning the regioselectivity of the Baeyer-Villiger oxidation of azabicyclic cyclobutanones 7 and 22 were also observed. The regiochemical outcome of these oxidations seem to be controlled by steric factors which somehow counterbalance the stereoelectronic bias imposed on the ring expansion of azabicyclic cyclobutanones.

\section{Acknowledgements}

This work was supported by a grant from the Research Support Foundation of the State of São Paulo (FAPESP: 99/06566-7). We thank Prof. Stephen F. Martin of the University of Texas at Austin, USA, for full experimental details of the decarboxylation procedure using acyl selenides, and Prof. Carol H. Collins (Unicamp) for reviewing the manuscript for its English usage. We also thank CNPq for fellowships.

\section{References}

1. For lead references on pyrrolizidine alkaloids and necine bases, consult: Liddell, J. R.; Nat. Prod. Rep. 2001, 18, 441; Harborne, J. B.; Nat. Prod. Rep. 2001, 18, 361, and the references cited therein; Trigo, J. R.; J. Braz. Chem. Soc. 2000, 11, 551; Roeder, E.; Pharmazie 2000, 55, 711; Hartmann, T.; Ober, D.; Top. Curr. Chem. 2000, 209, 207.

2. Rueger, H.; Benn, M.; Heterocycles 1982, 19, 23; Geissman, T. A.; Waiss Jr., A. C.; J. Org. Chem. 1962, 27, 139.

3. For previous synthesis of the Geissman-Waiss lactone and some closely related analogues, see: Wee, A. G. H.; Tetrahedron Lett. 2000, 41, 9025; Ohtake, H.; Imada, Y.; Murahashi, S. I.; Bull. Chem. Soc. Jpn. 1999, 72, 2737; Miranda, P. C. M. L.; Correia, C. R. D.; Tetrahedron Lett. 1999, 40, 7735; Murahashi, S.; Ohtake, H.; Imada, Y.; Tetrahedron Lett. 1998, 39, 2765; Knight, D. W.; Share, A. C.; Gallagher, P. T.; J. Chem. Soc., Perkin Trans. 1 1997, 2089; Kouyama, T.; Matsunaga, H.; Ishizuka, T.; Kunieda, T.; Heterocycles 1997, 44, 479; SanchezSancho, F.; Valverde, S.; Herradon, B.; Tetrahedron:Asymmetry 1996, 7, 3209; Cinquin, C.; Bortolussi, M.; Bloch, R.; Tetrahedron:Asymmetry 1996, 7, 3327; Paolucci, C.; Venturelli, F.; Fava, A.; Tetrahedron Lett. 1995, 36, 8127; Pandey, G.; Lakshmaiah, G.; Synlett 1994, 277; Cooper, J.; Gallagher, P. T.; Knight, D. W.; J. Chem. Soc., Perkin Trans. I 1993, 1313; De Faria, A.; Mattos, C. R. R.; Correia, C. R. D.;
Tetrahedron Lett. 1993, 34, 27; Tanaka, M.; Murakami, T.; Suemune, H.; Sakai, K.; Heterocycles 1992, 33, 697; Niwa, H.; Miyachi, Y.; Okamoto, O.; Uosaki, Y.; Kuroda, A.; Ishiwata, H.; Yamada, K.; Tetrahedron 1992, 48, 393; Takahata, H.; Banba, Y.; Momose, T.; Tetrahedron:Asymmetry 1991, 2, 445; Knight, D. W.; Share, A. C.; Gallagher, P. T.; J. Chem. Soc., Perkin Trans. I 1991, 1615; Thaning, M.; Wistrand, L. G.; J. Org. Chem. 1990, 55, 1406; Ikota, N.; Hanaki, A.; Heterocycles 1988, 27, 2535; Knight, D. W.; Share, A. C.; Gallagher, P. T.; J. Chem. Soc., Chem. Commun. 1988, 509; Niwa, H.; Okamoto, O.; Miyachi, Y.; Ousaki, Y.; Yamada, K.; J. Org. Chem. 1987, 52, 2941; and reference 2. ??

4. Oliveira, D. F.; Miranda, P. C. M. L.; Correia, C. R. D.; J. Org. Chem. 1999, 64, 6646; Carpes, M. J. S.; Correia, C. R. D.; Synlett 2000, 1037; Oliveira, D. F.; Severino, E. A.; Correia, C. R. D.; Tetrahedron Lett. 1999, 40, 2083; Severino, E. A.; Correia, C. R. D.; Org. Lett. 2000, 2, 3039.

5. For an excellent example of this strategy, see: Martin, S. F.; Chen, K. X.; Eary, C. T.; Org. Lett. 1999, 1, 79 and references cited therein.

6. For a comprehensive review on $[2+2]$ cycloadditions, see: Tidwell, T. T.; Ketenes; John Wiley and Sons: Toronto, 1995. For other reviews, see: Hyatt, J. A.; Raynolds, P. W.; Org. React. 1994, 45, 159; Wentrup, C.; Heilmayer, W.; Kollenz, G.; Synthesis 1994, 1219; Ghosez, L.; Brynaert, J. M. In Comprehensive Organic Synthesis; Trost, B.M; Fleming, I. eds; Pergamon: New York, Vol. 5, 1991, p. 85-122; Snider, B. B.; ChemTracts-Organic Chemistry 1991, 4, 403; Tidwell, T. T.; Acc. Chem. Res. 1990, 23, 273; Ghosez, L.; O’Donnell, M. J. In Pericyclic Reactions, Marchand, A. P.; Lehr, R. E. eds; Academic Press: New York, 1977, p 79-140.

7. Greene, A. E.; Kanazawa, A.; Gillet, S.; Delair, P.; J. Org. Chem. 1998, 63, 4660.

8. Pearson, D. A.; Blanchette, M.; Baker, M. L.; Guindon, C. A.; Tetrahedron Lett. 1989, 30, 2739.

9. For an extensive review on the Baeyer-Villiger oxidation of cyclobutanones and other ketones, see: Krow, G. C.; Org. React. 1993, 43, 251. For an updated review on BaeyerVilliger oxidations using transition metals, see: Strukul, G.; Angew. Chem. Int. Ed. 1998, 37, 1198.

10. Although uncommon, there are some precedents for regiocontrol of the Baeyer-Villiger by steric factors. For some illustrative examples, see: Dave, V.; Stothers, J. B.; Warnhoff, E. W.; Can. J. Chem. 1984, 62, 1965; Jacobi, P. A.; Walker, D. G.; J. Am. Chem. Soc. 1981, 103, 4611.

11. For the preparation of acyl selenides, see: Boger, D. L.; Mathvink, R. J.; J. Org. Chem. 1992, 57, 1429; Evans, P. A.; Roseman, J. D.; Garber, L. T.; J. Org. Chem. 1996, 61, 4880. For an outstanding application of the acyl selenides for decarboxylation, see ref. 5 .

12. An obvious solution to the regioisomeric problem would be 
the realization of the Baeyer-Villiger reaction with the dichloroazabicyclic cyclobutanone $\mathbf{6}$ followed by dechlorination. Unfortunately, this transformation led to low yields for the desired lactone 9 (i: $m$-CPBA; ii: $\mathrm{Zn}-\mathrm{Cu} / \mathrm{NH}_{4} \mathrm{OH}, \sim 20 \%$ yield) despite its complete regioselectivity towards the lactone, having the oxygen inserted at the C5-C6 bond of the bicyclic system. Unpublished results obtained by Mary Anne Souza Lima, Ph.D Thesis, Universidade Estadual de Campinas, Brazil, 1999.

13. Yoshifuji, S.; Tanaka, K.; Kawai, T.; Nitta, Y.; Chem. Pharm. Bull. 1986, 34, 3873.

14. Crystallographic data (excluding structure factors) for the structure reported in this paper have been deposited with the Cambridge Crystallographic Data Centre as supplementary publication $\mathrm{n}^{\circ}$. CCDC 183539. Copies of the data can be obtained free of charge on application to CCDC, 12 Union Road, Cambridge CB2 1EZ, UK [Fax: int. code + 44(1223)336-033; Email: deposit@ccdc.cam.ac.uk].

15. Farrugia, L. J.; J. Appl. Crystallogr., 1999, 32, 837.
16. North, A. C. T.; Phillips, D. C.; Mathews, F. S.; Acta. Crystallogr. 1968, A24, 351.

17. Altomare, A.; Cascarano, G.; Giacovazzo, C.; Guagliardi, A.; J. Appl. Crystallogr 1993, 26, 343.

18. Sheldrick, G.M.; SHELX97 - Programs for Crystal Structure Analysis (Release 97-2), Institüt für Anorganische Chemie der Universität, Tammanstrasse 4, D-3400 Göttingen, Germany, 1998.

19. The PhSeNa solution was prepared as follows: To an orange colored solution of $55 \mathrm{mg}$ of diphenyl diselenide $(0.17 \mathrm{mmol})$ in $1 \mathrm{~mL}$ of THF and $1 \mathrm{~mL}$ of $t-\mathrm{BuOH}$, at $0^{\circ} \mathrm{C}$, were added 13 $\mathrm{mg}$ of $\mathrm{NaBH}_{4}(0.34 \mathrm{mmol})$ and the reaction stirred until it turned colorless.

Received: April 18, 2002

Published on the web: October 25, 2002

FAPESP helped in meeting the publication costs of this article. 